\title{
The Impact of SDGs on International Law - A Nucleus of a Right to Peace?
}

\author{
Ursula Werther-Pietsch ${ }^{1, *}$ \\ 1 Karl-Franzens-University Graz, University of Vienna, Danube University Krems, Austria \\ * ursula.werther-pietsch@univie.ac.at
}

\begin{abstract}
The thesis of this article is to unpack potential impact of the 2030 Agenda for Sustainable Development of the United Nations on international law in the field of peacebuilding, and a right to peace in particular. It is argued that the issues of fragility, human security and resilience as stipulated in the Sustainable Development Goal(SDG) I6 of the Agenda created a valid entry point for steering transition from war to peace in a normative way. In fostering a comprehensive ius post bellum for societal change, this makes crystal-clear that the principle of self-determination functions as a meta-goal of the international order. The 2015 review of UN peacekeeping operations and the UN Security Council's resolution 2282/2016 regarding sustained peace sharpen this finding in contrast to new geopolitical trends. It can be summarized that peacebuilding and statebuilding strategies are serviced by insights of the new consensus preparing for a rare momentum to move forward a universal right to peace.
\end{abstract}

\section{Keywords}

Agenda 2030, right to peace, international law of transition, peacebuilding, statebuilding, resilience

\section{Die Auswirkungen der SDGs auf internationales Recht - Anstoß auf ein Recht auf Frieden?}

\section{Zusammenfassung}

Der Artikel untersucht die potentiellen Auswirkungen der Agenda 2030 der Vereinten Nationen für Nachhaltige Entwicklung auf das internationale Recht der Friedenssicherung und -konsolidierung, insbesondere auf ein Recht auf Frieden. Es wird argumentiert, dass die Festigung von Staaten, menschliche Sicherheit und Resilienz dazu beitragen, den Übergang von Krieg zu Frieden als einen normativen Prozess zu begreifen. Indem die Welt-Entwicklungsziele und das SDG I6 im Besonderen ein umfassendes ius post bellum für gesellschaftlichen Wandel vertiefen, wird klar, dass das Prinzip der Selbstbestimmung als ein Meta-Ziel der internationalen Ordnung wirkt. Die Überprüfung der Friedensoperationen der Vereinten Nationen im Jahr 2015 und die Resolution 2282/20I6 zu nachhaltigem Frieden des UN-Sicherheitsrates bestätigen diese Erkenntnis. Zusammenfassend kann gesagt werden, dass Peacebuilding- und Statebuilding-Strategien des neuen Konsenses weiterentwickelt werden, womit sich entgegen aktuellen geopolitischen Trends eine Chance für ein universelles Recht auf Frieden auftut.

\section{Schlüsselwörter}

Agenda 2030, Recht auf Frieden, Transitionsvölkerrecht, Friedenskonsolidierung, Staatsaufbau, Resilienz

The author has declared that no competing interests exist. 


\section{Introduction}

"Measuremania" spreads over a range of actors in the scientific and public domain of peacebuilding, statebuilding and development who are or deem themselves accountable to a global audience. Building peaceful and inclusive societies is part of the boldest framework for humanity, as UN Secretary-General António Guterres says, but how to measure potential progress? Especially when it comes to the impact of Sustainable Development Goals (SDGs) on international law.

SDGs as adopted by the UN General Assembly on 25 September 2015 comprise the most recent responses of the international community to save future human existence, shared economic development, a sane planet and living together in peace. Picking up the last point, mixed migration flows of global scale and conscience-shocking terrorist activities worldwide made all the more apparent that defining balances of power in fragile societies is one of the biggest challenges today (Die Zeit, No. 49, 3 Dec. 2015). Our answer hitherto has been a half-hearted one and somewhat incomplete, far from being holistic or visionary enough. Nor did it yet expand across different policy fields to reach better results together (EU Action Plan 2015, I4-I5; EU Global Strategy 2016, part III). This is the case in the following disciplines:

- Linking the concepts of security, sovereignty, inclusion and intervention figures amongst the most controversial reform projects in international law.

- Humanitarian actors struggle with unparalleled challenges of relief, rehabilitation, development, and peacebuilding. (World Humanitarian Summit 20I6).

- International crisis and conflict management, when it comes to the soft interface of civil-military cooperation, has changed from protection of civilians to the continued fight against terrorism.

- On top, we witness an ever increasing move from UN mandated intervention back to an allied or isolated end-of-I99os type of international operation.

- A dynamic response to non-state armed actors has meanwhile been initiated but is far from being resolved. (UNSC resolution I373, 2249, 2282)

This puzzle has been complemented by sustained humanitisation in all policy fields relevant to transition processes, and to peacebuilding and statebuilding in particular. Not only within the development community, the notion of sustained individualization firmly grounded in human rights and based on the concept of human security (Martin/Owen 2OIO, 2II-224; Hauck 2OI4, 3I4I; Otter 20I6) has steadily gained momentum until the new global SDG consensus emerged.
The 2030 Agenda for Sustainable Development absorbs all these dimensions and trends, the main message being that survival of mankind can only be granted under the precondition of peace and prosperity for all. The power of the SDGs to live up to transformative shifts such as "Leave no one behind" (preamble and para. 4 of the SDG Declaration UNGA resolution A/7O/L.I) will certainly continue to shape concerted action in the near future and beyond.

Acknowledging the apparent diversity of values worldwide, increasing intra-societal mobility and polarization facilitated by social media, and a probable remilitarization of international relations, it is however doubtful whether this status is satisfactory. How can underlying root causes of fragility be adequately addressed by the international community? Linked to that question, it is to be discussed how international law reflects lessons from the SDGs to pave the way for a consolidated normative perspective on transition from war to peace, which does not exist for the time being (Werther-Pietsch, forthcoming).

\section{Transformative Power of the Agenda}

The 2030 Agenda interacts with principles of international law by substantially framing its value-driven parts. On peace and security it obviously filled a gap. According to Preamble pt. 5 and op. 35 of the SDG Declaration, "sustainable development cannot be realized without peace and security; and peace and security will be at risk without sustainable development". For the first time and other than its predecessors the Millennium Development Goals (MDGs) which unilaterally targeted better development cooperation from North to South, the Agenda explicitly addresses predominant underlying factors of poverty, inequality and violent extremism that regularly meet with fragility. Let us take a short introductory look at these three root causes of crisis and conflict from a universal point of view.

\section{Poverty}

In 2030, 62 percent of the poor, i.e. I, 5 billion people will live in fragile situations, from Nigeria to Pakistan (OECD $2015,93)$. It is imperative, also with a view to cope with massive migration movements and worldwide highest numbers of internally displaced persons, that care for the powerless will manifestly guide strategies with a view to create perspectives on the ground. Whereas the MDGs were silent to state fragility, resilience of states is now systematically addressed as the no. I factor to overcome poverty at global level (UNDP/Worldbank, International Financial Institutions Spring Meetings, Washington D.C., 5 March 20I8). Being a highly sensitive matter, the security dimension of development has 
long been neglected by political leaders and donors as well, and will meet further resistance (Collier 2009, $29,34)$. The very challenge, in line with the findings of UNSC resolution 2282/2016 on sustained peace, will lie in disaster risk reduction, early warning and conflict prevention to make systems resilient.

\section{Inequality}

Discrimination and exclusion gaps are widening, a selfdetermined way of life is still a varied experience around the globe. Different levels of income in the USA, for instance, resemble those of the European countries before the outbreak of WWI (Piketty 2014, 22; Milanovic 2016, 134). A reference to self-determination as a prerequisite of equality and inclusion is to be found in SDG Declaration para. 35, albeit in its usual rather outdated context of colonialism. However, this principle has to reflect individual freedoms and capabilities as stipulated in article I of both Global Covenants on Human Rights in order to translate non-discrimination for all into reality. What is more, and despite the fact that from a scholarly horizon the connotation with independence of states seemed already obsolete (Cassese 1995, 335, Kadelbach 2006, 2I-40), we are nowadays confronted with a renaissance of autocracy and reluctance against the broadening of freedom worldwide.

\section{Violent extremism}

In recent years, constructive but critical engagement of civil society organizations for peace, human rights and democracy experienced a continued downward trend. (Peacebuilding Forum Berlin 2015) Shrinking space has been at the center of discourses of non-state actors since they work at the forefront of notoriously autocratic regimes. But this phenomenon is also true when radicalization in rather intractable and amorphous environments hit both authorities and populations. Administrative reaction seems to underline the observation that in such circumstances legislation all too often tends to cut down and restrain political life. Effective response to risks of violent extremism in weak states or ungoverned spaces is clearly a normative task and a question of political culture as well. (Meister, Neue Zürcher Zeitung, 2 February 2018) At subsidiary level, countering violent extremism through job creation, education for peace and dialogue are asked for (Roithner 20I4, 9I-93).

\section{Emergence of an intertwined solution}

What do these challenges mean to the way of handling fragile states by the international community, if there is a joint strategic effort on this issue at all? We have progressed along external engagement in fragile environments during the last two decades and reached a some- what mature if not cooled-down point. The protracted conflict in Syria as well as deeply destabilizing effects in the whole region, the emergence of the IS movement throughout Northern Africa and the Sahel, phenomena of mass flight and migration across continents prepared for considerable shifts in geo-strategic thinking (Feichtinger, ORF ZIB 2, 2I October 2015). Against this background ambitious mandates and hybrid civil-military peace operations falsified themselves.

It has been shown that one reason of the failure of external action so far lies in its state-centric design and ambition (Horta Report 2015). In a complementary way, SDG I6 calls for support of resilient and inclusive societies in their struggle for peace. Strategies include mediation and conflict transformation, dialogue and support for local facilitators in peace processes, access to justice, meaningful participation and fair institutions. (Federal Government of Germany 2017, 77) All these instruments are expected to effectively feed into balances of power within society. However, only four percent of total official development aid until now goes to legitimate politics underpinning stable political orders (OECD 2OI5).

The 20II World Development Report on Conflict, Security, and Development fairly characterized preconditions of workstreams (WDR 20II, 28-39), setting the scene for SDG negotiations in this respect:

(I) Ground-breaking evidence shows an average decline of up to 30 percent of the GDP when states are affected by crisis and conflict.

(2) The risk of weak or polarized, in many cases corrupt state institutions remains high throughout the whole transition phase.

(3) Given high levels of unemployment and growing hybridization of societies along ethnic, social and cultural lines, relapse into conflict is omnipresent, a fact that can last up to three decades.

(4) New actors and political elites may count for innovative drivers of change, but in most cases act to their own benefit and seek to derail stabilization.

(5) Violence has radically changed its face. Individuals and households in many cases are under permanent threat of organized crime. Trafficking in human beings has become one of the most dangerous playing fields along transition routes (Neumann 20I7).

As such, ending wars is seen today as an all-inclusive and eminently political process. Consequently, interpreting SDG I6 rightly means to put the focus on civil society as a primary driver of transition. Indeed, civil society, the state-citizen relationship and care for social cohesion is much more present in conflict transformation strategies than in any former institution building approaches. In tackling complex emergencies, this may be seen as part of a huge turn towards local communities and their re- 
silience mechanisms as stated in the World Disasters Report (2015, 86; UNOCHA 20I7) Reflecting this, the Agenda already reaches out and embraces both national and more subsidiary levels of governance. (UNGA resolution A/RES 70/I para. 6, 39-52, 60) International law could follow these insights.

\section{Extending the New Consensus: SDGs and Inter- national Law of Transition}

\subsection{Innovation in the light of individualization}

SDGs - as has been argued in chapter 3 - highlight the very foundations of the well-being of people in peace and the realization of individual chances and capabilities. Despite the fact that the Agenda is an instrument of soft law, this can be considered as a substantial step forward in normative terms.

In that sense and far beyond its socio-economic and ecological pillar, the SDGs offer a universal counternarrative against radicalization and violent extremism, conflict and disorder. The task that arises now is to concretize impact to be derived from the SDG perspective on peace architecture. Since the interface between security and development progressively forms part of broader constitutionalisation processes in international law, we might detect a convergence with ongoing debates on a "Kantian plus" project, i.e. the creation of a consistent body of international law leading up to a status where states internally perform along globally agreed constitutional principles. This would shape international relations beyond the UN Charter respectively.

In this context, the new emphasis on political settlements based on inclusion and empowerment of civil society comprises a two-fold strategy: Not only mechanisms of balancing interests and social cohesion, thus civil society as an object, have proven to be crucial on the way to democratisation. Civil society as a subject itself, thus its vital role as an actor in transition, has become center-stage (e.g. West African Network for Peacebuilding). Therefore, attributing responsibility to non-state actors and holding them legally accountable is essential from an international law perspective, as has been reiterated by the Stockholm Declaration of the High Level Global Meeting of the International Dialogue on Peacebuilding and Statebuilding on 5 April 2016.

That is why a possible future law of transition could take up and would be well-grounded in a modified human security approach to development. Normatively, transition is based on the three intrinsically linked and mutually reinforcing pillars of the UN Charter, peace and security, human rights and development (UNGA resolution A/RES/60/I para. 9). Human security from the very beginning encompassed all strands of schol- arly thinking of the individual and the society being the primary subject of security as opposed to its previously predominant territorial, military and defense dimension. In the era of globalisation, communication and inter-connectedness paired with increased operability of non-state actors, a few human security scholars went on to advocate individualization throughout global governance and individuals being the primary subjects of international law (Parlett 2011, 336f; Peters 2009, 543). Indeed, the fact that ungoverned spaces with highly fragile external effects are expanding calls for a renewed human security concept with more transformative power. We may think of strongholds of war lords, factions, armed groups in Iraq and Kurdistan, Libya or South Sudan, the Russian neighborhood "cordon" from EastUkraine to Azerbaijan as well as large-scale suppression in South-East Asia, Myanmar and China respectively. Human security today presents itself in its third generation, progressing from the needs and capabilities of individuals towards advocating, defending and promoting rights of groups, social cohesion in societies and a renewed principle of self-determination in statebuilding (Prinz/Schetter 2014, 92-IOI; Werther-Pietsch 20I4, 47-53).

\subsection{The late success of Human Security}

A preliminary definition of human security and what it meant to the international community over the last two decades was sealed by the UN on Io September 2012. At that time the UN General Assembly agreed on a "Common Understanding of Human Security" (UNGA resolution 66/290). After extensive plenum debates, this consensus demonstrated a consolidated albeit narrow basis of the notion of individualized security. Bruno Simma, former judge at the International Court of Justice in The Hague, is correct in categorizing this career of a term as "overstretched, inconclusive, and therefore still alive" (Simma 2009, 266). However, to better grasp the impact of human security globally, the following steps of its genesis in 2012 may be recalled.

On the one hand, a group of mostly Western industrialized countries relying on an intervention-friendly, integrated, people-centred, contextualized, idealistic perspective on human security argued their position as UN home-grown and compatible with the system. Their way of thinking was further supported by para. 44 of the 2009 UNGS Report on Peacebuilding in the Aftermath of Conflict: "The aim of the international community is [...] to help building resilient societies" (UNGS 2009b), a wording that has recently been echoed by the EU Global Strategy $(2016,3,15)$. This conceptualization is based on a longstanding extensive interpretation of the UN Charter with a view to a comprehensive approach for peace and security (Herdegen 2007, 285f; Hilpold 2013, I8) 
Nevertheless, main features of the compromise were formulated by a group of states insisting in a traditional interpretation of state sovereignty, thereby largely rejecting the idea of external action relying on article 2 (7) of the UN Charter. At the same token, and in a more autocratic than peace-loving mood, these states oppose to implement the universal freedoms. The result looks like the final wording of para. 4 of the above quoted UNGA resolution 66/290 (2012): "Whereas human security recognizes inter-linkages between peace, development and human rights, it is distinct from the responsibility to protect $(\mathrm{R} 2 \mathrm{P})$; does not replace state security; and has to be implemented with full respect for the purposes and principles of the UN." In search for compromise the EU confirmed the obvious delinking human security from $\mathrm{R} 2 \mathrm{P}$ and welcomed the UNSG's considerations in this regard. Until now, there has been no sign of revising that position. This approach does not seem to be tenable any longer.

With that in mind, SDG I6 renews the stimulus of an emerging international law of transition directed toward functional state structures and governance in the light of the bottom-up perspective "Leave no one behind." In this sense, a strong argument can be derived from the SDG framework for sustained peace: If the old International "Lotus" Order (PICJ I927) is to survive and will preserve itself from breakdown or total collapse in an extensively interconnected world, it must take care of weak members in its own interest through a commitment to diversity, obligatory elements of inclusive and just state institutions, and an opening up to non-state actors at large (Fritze 2017, 185-200), all of them a late success of the concept of human security.

\subsection{Towards a Responsibility to Build}

It would however be too narrow to speak of a "responsibility to rebuild after conflict", as discussed since around 2010 (de Brabandere 2010) and put forward by Carsten Stahn (2OI4). Emanating from the argument in chapter 4.2 , it rather appears promising to extend the case in order to pick up all forms of self-determination in emerging states. A holistic "responsibility to build“ (R2B) would enable the international community to neutralize its action as one that is not directed against someone but a path of mutual advantage for all. Independence of South Sudan, though to a limited extent, is a case in point.

Legally speaking, to perform this extension one may well be advised to uncover effects of state responsibility and postulate a corresponding ex-ante, subsidiary responsibility of the international community by concretizing pillar I and 2 of $\mathrm{R}_{2} \mathrm{P}$. In addition to the evidence-based argument derived from the SDGs, this would be based on an implied powers model: External actors when pushing for resilient and peaceful societies together with fragile states themselves, will have a joint mandate from the new consensus arising to a positive obligation to reach the goal of peace and security and remedy paucity in statehood in a sustainable manner. The Peacebuilding and Statebuilding Goals (PSGs) which were adopted $201 \mathrm{I}$ by the International Dialogue on Peacebuilding and Statebuilding between fragile states and OECD already reveal such pathways out of fragility. A joint way of thinking called "shared sovereignty" is in the making, maybe overruling older models and wellknown objections. (see section 5)

Finally, to empower the legal argument strategically, the sovereignty debate (Pospisil, forthcoming) advocated here might find support in the peacekeeping discourse. In accordance with UN Charter based provisions, weak and failed states traditionally ended up in transitional governance models such as trusteeships or conditional statehood. A prevalence for sovereignty as responsibility could only be established since 1999 (Annan 2005). This notion is reiterated in recent analyses in the peacekeeping realm. Strong incentives for responsible sovereignty are to be found in the 2015 Horta Report reflecting lessons identified from the International Security Assistance Force (ISAF) mission in Afghanistan in particular. (Hannemann in Werther-Pietsch 2013, I89-190) Though meeting with severe difficulties in implementation, in this mission the USA developed a people-centred Counter Insurgency approach (COIN). The so-called Provincial Reconstruction Teams (PRTs) installed to communicate with local populations had to respect local leaders on an equal footing. (del Castillo, 2OII) Failing largely to perform its own predominant security interests of detecting terrorist cells, the approach in it-self had to face serious backslashes. Without a long-lasting perspective for local governance structures, progress on the ground remained volatile. This is equally the case for targeted support for grass-roots women, acting in an isolated manner, when irresponsive to Afghan societal patterns.

Ultimately, as has been stated by Martti Koskenniemi in 2009, a "vocabulary above sovereignty" is needed (Koskenniemi 2009, 8). Annie Bird from the London School of Economics relentlessly reveals exactly this normative quality of ius cogens, decisive for the implementation of a $\mathrm{R}_{2} \mathrm{~B}$, addressing the opposite eloquently as "straightjacket of bilateralism". (Bird 2010, 897) Unfortunately, in the real-world, the national domaine réservé seems to remain an unconquerable fortress of sovereign rulers. Having repeatedly been rejected in favor of universal erga omnes norms when gross and massive human rights violations occurred (Meron 2006, 24, 4I), it practically regained power and, with the resurgence of geopolitics, is there to stay. 


\section{A theory of change in times of crisis: Shared Sovereignty}

\subsection{The benefits of balanced diversity}

What conclusions to be drawn at this stage? With its focus on well functioning institutions as well as the rule of law as foundations of democratisation, SDG I6 slightly converges with liberal peace theories concentrating on conducive frameworks for peaceful change. It is noticeable though that it acknowledges peacebuilding including the reestablishment of genuine political and constitutional checks and balances, accountability and mechanisms for the peaceful settlement of disputes to need civil society as drivers of reform. As argued in chapter 4.3, work at all levels of power and political elites should pursue the common project of transition as one that has to do with ownership and meaningful inclusion of the marginalised and vulnerable. This concept of "shared sovereignty" is valid in all places of the world, the Ukraine, the Western Balkans (Dzihic 2012, I3-I6), East-Timor, Somalia or Liberia.

On the whole, the spirit of the Agenda 2030 follows Roger McGinty's recommendation, "that international interveners should remain more open-minded as to the legitimacy of local forms of political organization, become more creative in responding to these forms of legitimacy, and less assured and ready to roll out liberal international blueprints" (2010, 39I). Almost ten years later, and very much in line with the International Dialogue on Peacebuilding and Statebuilding, practice overwhelmingly confirms that it is important to focus on actors, not only on institutions. The more localization of the political life is accepted to be a decisive factor for successful transformation, the more legitimate action on the ground can take place to contribute to realize balanced diversity as a prerequisite for peace.

Following Joel Migdal (1988), Jean Paul Lederach (1995), Otto Czempiel (2003), Günter Teubner (2006), Parag Khanna (2008), Michael Pugh (2008, I30) and Daniel Thürer (2009), this approach should lead to ever higher levels of self-determination in a pluralistic form, countering fragmentation, polarization and hybridization of societies in general (Werther-Pietsch/Ritzer 2013, 46f). This theory of change reinterprets sovereignty in a flexible "fuzzy" way favoring decentralized governance and a balanced distribution of power on the one hand. On the other preventive, non pre-emptive action is seen as an essential and effective playing field for building resilient statehood (Worldbank/UNDP 2018).

\subsection{Lessons from International Crisis and Conflict Management}

What follows is that all peacebuilding and statebuilding strategies have to address civil society needs. What is more challenging, they are to promote political settlements and governance at the local level. This has been underpinned by the outcome of the 2015 revision of the UN Peacebuilding Commission and the implementation of UNSC resolution 1325 with regard to the elementary role of women in armed conflict. One of the main findings of the analyses emphasized that building states should respect diversity and dialogue. The hypothesis calls for core functions of the state to be specified by external actors with a view to create open space for citizens' engagement (see also Ghani/Lockhart/Carnahan 2006, IOI)

These conclusions are largely supported by evidence. Number of case studies shows that where people-centred strategies conducted in the self-interest of intervening external actors failed because they instrumentalized local actors without being careful enough to serve the goal of progress on the ground. (e.g. Hippler 20IO, 63) It has become crystal-clear that combining one's own security interests with sustained peace needs more than a short superficial glance at local structures.

Moreover, the conclusions find broad support in the development discourse. The area of tension between the state and the societal sphere - who takes the lead? - is one of the major discussions that guided debates in the International Network on Conflict and Fragility of the OECD. It is convincing to assert that the interface between peacebuilding and statebuilding has conceptually generated the same message. (OECD Statebuilding Guideline 20IO, 3) This interconnectedness making the core function of civil society more transparent was deepened and systematized in the meantime (Rocha Menocal 20I0). The insight was taken a step further in recent research work that puzzles and recreates statebuilding from the human rights angle and constructs peace processes as processes of increased levels of selfdetermination. (Werther-Pietsch 2015, I2-2I)

As cooperation between state and non-state actors gets ever more compacted, one can conclude with Samantha Besson (20I2) that the (inter-)national community is one of "different albeit inter-dependent actors". Indeed, in order to dissolve the specificities of power transition, the ever revolving pitfalls turn out to lie in procedural human rights questions of inclusion, demanding a firm opening of peace processes beyond the state sphere. What incentives could be offered by a normative regime to gain systematic advantages by collaboration with civil society leaders? With a view to overcome the challenges of young statehood to be inserted 
in the concert of nations, it is proposed to work towards an international law of transition based on a right to peace. How would it look like? What are its essentials?

\section{Rethinking a Right to Peace}

An ongoing fierce debate reveals deficits around the notion of a ius post bellum (IPB), this third post-Grotian category between ius ad bellum and ius in bello. Opinions covering alternative scopes of normative ways out of conflict and fragility comprise ideas from a self-contained regime with the aim of exclusive ruling, the proposal of a Fifth Geneva Convention (Orend 2008) or a principled interpretive space. (de Brabandere 2012; Bell 20I4) Flashing back to chapter I, only a holistic and consistent approach to Heraklit's "gignomenon" and "phainomenon" reflecting the fragile human condition seems to tackle the posed problem.

The idea of viewing transition as a separate normative regime is in a sense broader than ius post bellum and part of the wider trend of Kantian constitutionalisation of international law. (Martineau 2009, 25) The proposed approach encompasses emerging societies from colonial status, failed and threatened states to young states under construction. From this point of view the broader application of the SDGs replaces the former right to development as stipulated in UNGA resolution $4 \mathrm{I} / \mathrm{I} 28$ of 4 December 1986 which was still characterized by a clear North-South dialectic.

The right to development debate constituted a huge post-imperial project but remained non-enforceable in political terms at any point in history. Later absorbed and softly bypassed by other relevant regimes such as the New International Economic Order and the World Trade Organisation, as well as regional arrangements like Conventions of African, Caribbean and Pacific (ACP) States with the European Union and other regional integration processes, it was slowly but steadily pushed back to a second-stage forum. (Scherling 2016, 345) Finally, the 1993 Vienna World Conference achieved a major breakthrough for universality and indivisibility of the whole human rights regime, as a basis for selfdetermination that has already been part and parcel of the 1986 resolution.

In as much as the SDGs favor a new form of selfdetermination, they clearly unfold a measurable impact on international law, at least reinforcing principles by re-interpretation. Sovereignty becomes shared and diversity balanced as the ultimate or meta-goal for development and prosperity. Originally stemming from the decolonization era some 30 years ago, the principle of self-determination is stipulated in the UN Charter and respective UN Security Council and General Assembly resolutions (1514/1960 - Declaration on the Granting of Independence to Colonial Countries and Peoples, 377/1950 - Uniting for Peace, 2526/1970 - Friendly Relations Declaration) It was revisited and enlarged when the concept of responsible sovereignty put a new emphasis on the individual outside the colonial context. (Annan 2005) This is meant when human security and human rights are used as provocative and transformative concepts - here the silent but effective residuals of international law as asserted by the International Court of Justice in its 20Io Kosovo Advisory Opinion become very telling. The big paradigm change lies in a universal, shared approach to decisively end the North-South and seemingly obsolete state/non-state dichotomies of selfdetermination.

"Leave no one behind" is the SDGs' youngest but strong formula, aptly questioning the old order of states in its Westphalian configuration. Human rights with their acknowledged positive protection obligations have nourished human security as the catalyst of individualization and self-determination beyond the state ("fuzzy sovereignty"). Nevertheless, human security remains the driving force and prima inter pares to give this impetus a new imprint.

These impulses may overcome the impasse of the hitherto inconclusive deliberations on a "right to peace" of the UN working group and the respective draft $\mathrm{Hu}-$ man Rights Council (HRC) resolution adopted in 2016, without eliminating the opposing frontiers. Within the HRC this has not come with surprise, given the fact that an explicit human rights-based approach of the SDGs as well could not reach consensus throughout the whole inter-governmental negotiations. The Security Council, in a further tactical shift of the UN in 2016, rather gathered around UNSC resolution 2282 putting sustained peace in the middle of interest.

\section{Road Maps to Peace - how they could work}

On the basis of this resolution, certain innovations seem to be in near reach: From the scholarly side, in her work comprising a systematization of the largest data collection worldwide on components of peace agreements, Christine Bell of the University of Edinburgh Law School depicts fields of political weight for that purpose (launch on 20 February 2018 at British Academy in London). Wolfgang Petritsch in elaborating a best-of list for successful peace negotiations contributed highly relevant elements (Petritsch 20I3). Inspired by his work at Harvard University, a set of recommendations was prepared to translate the 2007 OECD DAC Fragile States Principles into "Principles for Responsible Peacebuilding and Statebuilding". (Werther-Pietsch in Nowak/ Werther-Pietsch 2014, 233) Carsten Stahn pioneered for a broader international law of transition from 2008 on- 
wards and centered on the issue in 20I4. (2008, 23I-239; Leiden Project Group)

The following procedural aspects of a "lex pacificatoria" drawing on Larry May's five substantial principles - rebuilding, retribution, reconciliation, restitution, reparation and proportionality (2OI2) - reflect the three root causes of conflict and fragility outlined and try to give remedy to the wider governance gaps analyzed above. They show what a novel application of the selfdetermination legal norm that serves to transcend and therefore reconcile its inherent tension between territorial integrity and representative governance could perform: It attempts to respond to demands for external and internal self-determination by fashining hybrid political solutions that combine both elements. (Bell in Stahn 20I4, I85) This is a late but constitutive echo to the UNGS in 2009 when focusing the first time on building inclusive and peaceful societies by "support for political processes, including electoral processes, and promoting inclusive dialogue and reconciliation." (UNGS 2009) Self-determination could in that procedural dimension serve as a guiding principle in determining the interplay of international and domestic law, in case an international operation intervenes.

Road Maps to Peace concretizing the suggested "R2 $\mathrm{B}$ " would carry on the following elements:

- Self-determination: Steering transition politically, based on "fuzzy sovereignty" in inclusive peace processes. To do: Open up to the non-state sphere.

- Early action and conflict prevention: Joint fragility assessments and transition as a basis for the scope of peace agreements (de Burca 2008) and dynamic synopsis of all actors including non-state ("buy-in clauses"). To do: Be inclusive, but freeze out extremism.

- Gender-responsiveness: Inclusion and integration of women and their ambitions as indicators and benchmarks on the way to sustained peace. To do: Connect with positive effects as demonstrated in the new data base of peace processes.

- Diversity: A new dimension in accordance with international migrationpolicies emphasizing human rights and creating perspectives on the ground. To do: Promote the nexus between immediate humanitarian care and instruments of development cooperation.

- "Applied rule of law" - accountability and integration: Transitional justice, amnesties and the fight against radicalization to be seen as an interwoven package. To win a war in the $2 \mathrm{I}^{\text {st }}$ century, says Guglielmo Verdirame $(2013,307)$, you need your former enemy.

- Comprehensive/Integrated Approach: Create enhanced and transparent rules for accountability of external actors, alignment of international humanitarian action and law on conflicts with human rights. (Fleck 2008) To do: Bring together insights and expertise of all communities and negotiation places. (Starlinger 2012, I37-I48; Vienna 3C Appeal 20IO)

All in all, peace processes from a human rights/human security perspective can be qualified as emanations of lasting self-determination. Balancing sovereignty with self-determination („suspended” territorial integrity, Werther-Pietsch) is a far-reaching concept which proposes a new approach to protracted, asymmetric, internal and/or internationalized conflicts. Additionally, potential impact on state criteria beyond Bluntschli and Jellinek, progressive individualization, mediation and trans-territorial forms of interim governance have to be explored in order to concretise a responsibility to build. "Road Maps to Peace" would then figure as the legal basis of a right to peace and as corner stones for joint strategies of contextualized peace frameworks. This would give a right to peace its real shape.

Whether such temporary adjustment requires a special legal regime or simply a clear entry and exit point, to be governed by adapted principles of international law during the transition phase, remains to be veryfied empirically. In setting time lines, hardliners of state sovereignty could be stimulated to move.

\section{Keeping up with realities}

Thus, SDG implementation in the fields of conflict and fragility could indeed serve as the cradle of a "right to peace". This in the end would make them highly relevant for international relations and our final embarkment from "apology to utopia". (Koskenniemi 2005)

The case has been made for a cautious relativization of state sovereignty to introduce and establish effective governance in fragile contexts. Not only the 2030 Agenda, but also the 2012 Common Understanding of Human Security as well as other documents of international contract and soft law such as the African Union Charter, the ACP-EU relations currently renegotiated, the new EU Global Strategy or resolutions of the UN Security Council on peacebuilding and mediation show that this inner dimension of sovereignty as a constitutional pillar in the Kantian tradition gains ground.

De lege ferenda, and in a complementary way, recognition of states should have to be made dependent on progress in the realization of sustained peace, human rights and self-determination. Early state practice, such as Verbal Notes with regard to the recognition of the Kososvo or op. 2/1992 of the Badinter Commission, followed by a series of UN resolutions - 688/9I (Kurdistan), 794/92 (Somalia), 940/94 (Haiti), 77I/92 (Bosnia and Herzego- 
vina), I070/96 (Sudan), I203, I244/99 (Kosovo), I272/99 (East-Timor), I368, I373 (Libya) - go in this direction. We may as well conclude that decision makers relying on a temporary mandate will have to live up to aspirations, so that the assumption applies: „Self-determination is a principle that $[\ldots]$ underlies the whole international order" (Thürer 2009, 472).

The "responsibility to build" shall serve as a frame for concretizing "Roadmaps to Peace" relying on the consensus made in the first and second pillar of R2P. (Kotzur, statement at the German Society of International Law, Berlin I5 March 20I7) This will however only work by full application of the third robust pillar of $\mathrm{R}_{2} \mathrm{P}$ in international crisis and conflict management which is ultimately able to save the seriousness of the approach when put into pressure. (Food for Thought Paper, National Defense Academy 2015)

It may be considered that questions of peace and security were often not solved at the official (track I) negotiation table, but by the powers behind in a confidential setting. We must not bypass this reality. To the contrary, each and every peace process will have to sort out how the principles of the framework of a lex pacificatoria as proposed in chapter 7 span a middle space for individual solutions between accountability, justice, prosperity and peace for all.

If the multitude of non-state actors become part of the game, a new type of instrument of international law comes into being, namely "whole-of-actors" Roadmaps to Peace with binding effects on all partners involved. Non-state actors as the primary addressees and bearers of a potential right to peace shall be empowered to participate, if not take the lead in such constitutive endeavors where it is first and foremost just process that matters. To learn and to revise carefully has never been forbidden. (World Disasters Report 2015, I84)

\section{Literature}

Afghan Women's Call, https://www.onebillionrising. org/34250/afghan-womens-one-billion-rising-riserevolution-call/ (accessed 04/O2/2018).

Annan, Kofi (2005), In Larger Freedom: towards development, security and human rights for all (UNGA resolution A/59/2005 as of 2I March 2005), http:// www.un.org/en/ga/search/view_doc.asp? symbol= A/59/2005 (accessed 04/02/2018).

Annan, Kofi (1999), Two Concepts of Sovereignty, The Economist, I6 September 1999.

Bell, Christine (2014), Of Jus Post Bellum and Lex Pacificatoria: What's in a Name, in: Stahn, Carsten/Kleffner Jann K. (eds.), Ius Post Bellum: Towards a Law of Transition Form Conflict to Peace, Berlin - Heidelberg: Springer, I8I-206.
Bell, Christine/Pospisil, Jan (2017), Negotiating Inclusion in Transitions from Conflict: The Formalised Political Unsettlement, in: Journal of International Development, 29:5 (2017).

Besson, Samantha (2012), Sovereignty, Max Planck Encyclopedia of Public International Law, http://mpepil. com (accessed 04/02/2018).

Brabandere de, Eric (2012), The Responsibility For PostConflict Reforms: A Critical Assessment of Jus post bellum as a Legal Concept. In: Vanderbilt Journal of Transnational Law 43, I26-I32.

Cassese, Antonio (1995), Self-determination of peoples: A legal reappraisal, Cambridge: Cambridge University Press.

Collier, Paul (2009), Gefährliche Wahl. Wie Demokratisierung in den ärmsten Ländern der Erde gelingen kann, Munich: Siedler.

Countering Violent Extremism and Radicalisation that Lead to Terrorism: Ideas, Recommendations, and Good Practices from the OSCE Region, Report by Professor Peter R. Neumann, International Centre for the Study of Radicalisation (ICSR), King's College London, as presented at OSCE Council of Ministers, Vienna Hofburg, 28 September 2017.

Czempiel, Ernst-Otto (2003), Weltpolitik im Umbruch. Das internationale System nach dem Ende des OstWest-Konflikts, $4^{\text {th }}$ edition, Munich: C. H. Beck.

De Brabandere, Eric (2010), The Responsibility For PostConflict Reforms: A Critical Assessment of Jus post bellum as a Legal Concept. In: Vanderbilt Journal of Transnational Law 43, II9-I49.

De Burca, Grainne (2008): Developing Democracy Beyond the State, Columbia Journal of Transnational Law Vol. 46 No. 2 (2008) 22I-278.

Del Castillo, Graciana (20II), The Economics of Peace: Military vs. Civilian Reconstruction - Could Similar Rules Apply? Paper prepared for the Conference on Expeditionary Economics: Towards a Doctrine for Enabling Stabilization and Growth, West Point, 2426 May 2011.

Dzihic, Vedran (2012), Dilemmas of Young Democracies in the Western Balkans 20 Years after the Dissolution of Yugoslavia, in: Dihic, Vedran/Hamilton, Daniel (eds.), Unfinished Business. The Western Balkans and the International Community, Washington D.C.: Center for Transatlantic Relations, Paul H. Nitze School of Advanced International Studies, Johns Hopkins University.

EU Action Plan (2015), Progress Report on the implementation of the EU's Comprehensive Approach to external conflicts and crisis - Action Plan 2015, Brussels: Joint Staff Working Document, I8 July 2016.

EU Global Strategy (2016), Shared Vision, Common Action: A Stronger Europe, http://europa.eu/global- 
strategy/en/global-strategy-foreign-and-securitypolicy-european-union (accessed 04/02/2018).

Federal Government of Germany (2017), Guidelines on Preventing Crises, Resolving Conflicts, Building Peace, Berlin.

Feichtinger, Walter, Konfliktanalyse Syrien, ORF ZIB 2 Interview, 2I October 2015.

Fleck, Dieter (2008), The Handbook of International Humanitarian Law, Oxford: Oxford University Press.

Food for Thought Paper, Protection of Civilians, Austrian National Defense Academy (NDA), Annual Symposium 2015 (Ursula Werther-Pietsch, with comments by Thomas Starlinger and Peter Hilpold).

Fritze, Lothar (2017), Kritik des moralischen Universalismus. Über das Recht auf Selbstbehauptung in der Flüchtlingskrise, Schöningh: Schönburger Schriften zu Recht und Staat.

Ghani, Ashraf/Lockhart, Clare/Carnahan, Michael (2006), An Agenda for State-Building in the Twenty-First Century, in: The Fletcher Forum for World Affairs 30/I, IOI-I23.

Hannemann, Andreas H.(2012), Afghanistan, in: WertherPietsch, Ursula, Staatsaufbau als Konfliktprävention, Berlin-Wien-Graz: Neuer Wissenschaftlicher Verlag, I85-192.

Hauck, Volker (2014), Gaps between Comprehensive Approaches of the EU and EU member states. Scoping Study, European Centre for Development Policy Management (ecdpm), Maastricht.

Hilpold, Peter (2013), Schutzverantwortung und humanitäre Intervention in historischer Perspektive, in: Hilpold, Peter (ed.), Die Schutzverantwortung $(\mathrm{R} 2 \mathrm{P})$ - Ein Paradigmenwechsel in der Entwicklung des internationalen Rechts? Leiden: Martinus Nijhoff Publishers, 59-I22.

Hippler, Jochen, Die neue Afghanistan-Strategie der Regierung Obama, Fröhlich, Christiane/Johannsen, Margret/Schoch, Bruno/Heinemann-Grüder, Andreas/Hippler, Jochen (eds.), Friedensgutachten 20IO, Berlin: Lit Verlag (2010) 63-75.

International Court of Juctice, http://www.icj-cij.org/.

International Federation of the Red Cross and Red Crescent Societies (IFRC) (2015), World Disasters Report (WDR). Focus on local actors, the key to humanitarian effectiveness, Geneva, http://www.ifrc.org/wdr 2015 (accessed 04/02/2018).

Janik, Ralph (2013), The Responsibility to Protect as an Impetus for Secessionist Movements, in: Kettemann, Matthias C. (ed.), Grenzen im Völkerrecht, Vienna: Jan Sramek Verlag, 4I-66.

Khanna, Parag (2008), The Second World, New York: Random House.

Koskenniemi, Martti (2005), From Apology to Utopia, The Structure of International Legal Argument, Reissue with a New Epilogue, Cambridge: Cambridge University Press.

Koskenniemi, Martti (2009), The Politics on International Law - 20 Years Later, European Journal of International Law Vol. 20 No. I, 7-I9.

Lederach, Jean Paul (1995), Preparing for Peace: Conflict Transformation Across Cultures, Syracuse University Press.

Martin, Mary/Owen Taylor (2010), The second generation of human security: lessons from the UN and EU experience, International Affairs 86: I, 2II-224.

Martineau, Anne-Charlotte (2009), The Rhetoric of Fragmentation: Fear and Faith in International Law, in: Leiden Journal of International Law Vol. 22 (2009) I-30.

May, Larry (2012), After War Ends, Cambridge: Cambridge University Press.

McGinty, Roger (2010), Hybrid Peace: The Interaction between Top Down and Bottom Up Peace, in: 4I Security Dialogue 39I.

Meister, Stefan, Putins schöne neue Weltordnung gewinnt mehr und mehr an Realität, Neue Zürcher Zeitung, 2 February 2018.

Meron, Theodor (2006), The Humanization of International Law, The Hague Academy of International Law Monographs Vol 3, Leiden - Boston: Brill.

Migdal, Joel (1988), Strong Societies and Weak States: State-Society Relations and State Capabilities in the Third World. Princeton, NJ: Princeton University Press.

Milanovic, Branko (2016), Die UnGleiche Welt, Berlin: Suhrkamp.

Nowak, Manfred/Werther-Pietsch, Ursula (eds.) (20I4), All Human Rights for All. Vienna Guidebook on Peaceful and Inclusive Societies, Vienna - Graz - Antwerp: nwv-intersentia.

OECD (20I0), Guidance on International Support to Statebuilding in Situations of Fragility and Conflict, Paris: OECD.

OECD (2015), States of Fragility Report, http://www.oecd. org/dac/governance-peace/conflictandfragility/ rf.htm (accessed 04/02/2018).

Orend, Briand (2008), Ius Post Bellum: A Just War Theory Perspective, in: Stahn, Carsten/Kleffner Jann K. (eds.), Ius Post Bellum: Towards a Law of Transition Form Conflict to Peace, Berlin - Heidelberg: Springer.

Otter, Lena (2016), Is the New Deal the Real Deal? Master's thesis at the Fachhochschule Burgenland.

Parlett, Kate (20II), The individual in the international legal system: continuity and change in international law, Cambridge Studies in International and Comparative Law No. 75, Cambridge: Cambridge University Press.

Peacebuilding Forum Berlin, I/2 October 2015, http:// www.frient-peacebuilding-forum.de/. 
Permanent Court of International Justice (PCIJ) (1927), The Case of SS „Lotus“, 7 September 1927, http:// www.icj-cij.org/pcij/serie_A/A_IO/30_Lotus_Arret. pdf (accessed 04/02/2018).

Peters, Anne (2013), Jenseits der Menschenrechte. Die Rechtsstellung des Individuums im Völkerrecht, Tübingen: Mohr-Siebeck.

Peters, Anne (2009), Humanity as the A and O of Sovereignty, in: European Journal of International Law Vol. 20/3, 513-544.

Petritsch, Wolfgang (2013), in: Collier, Robert, World's best diplomats: Here's how to achieve peace in Syria. Six essential lessons and suggestions of those who ended wars from Central America to Bosnia, Yemen to Afghanistan, Io September 2013.

Piketty, Thomas (2014), Capital in the Twenty-first Century, Cambridge - London.

Pospisil, Jan (2017), 'Unsharing' sovereignty: g7+ and the politics of international statebuilding, International Affairs.

Prinz, Janosch/Schetter, Conrad (2014), Das Ende der Souveränität? - Über die Entstehung neuer Gewalträume im Krieg gegen den Terrorismus, in: Die Friedens-Warte 89/3-4, 9I-IO9.

Pugh, Michael (2008), Challenges of Post-Conflict Intercession: Three Issues in International Politics, in: Stahn, Carsten/Kleffner Jann K. (eds.), Jus Post Bellum. Towards a Law of Transition From Conflict to Peace, The Hague: T.M.C. Asser Press, II5-I3O.

Rocha Menocal, Alina (2010), State-building for peace: a new paradigm for international engagement in postconflict fragile states, European University Institute Working Papers 34, Florence: Robert Schumann Center for Advanced Studies.

Roithner, Anna Katharina (20I4), Gewaltprävention und -reduktion in sozialen Gemeinschaften als Basis für lokale Entwicklung, in: Werther-Pietsch, Ursula (ed.), Trends und Innovationen im zivilen Krisen- und Konfliktmanagement - Optionen für Österreich, Series of the Austrian National Defense Academy I/I 4 Vienna, 7I-IOO.

Scherling; Josefine (2016), (K)ein Recht auf Frieden? Zum Verhältnis von Menschenrechten und Frieden, in: Wintersteiner, Werner/Wolf, Lisa (Hg.), Friedensforschung in Österreich - Bilanz und Perspektiven, Jahrbuch Friedenskultur 2015, Klagenfurt: Drava Editions, 333-350.

Simma, Bruno (2009), Universality of International Law from the Perspective of a Practitioner, in: European Journal of International Law Vol. 20 No. 2, 265-297.

Stahn, Carsten (2008), The Future of Jus Post Bellum, in: Stahn, Carsten (ed.), Jus Post Bellum. Towards a law of Transition From Conflict to Peace, The Hague: T-M-C Asser, 23I-237.
Stahn, Carsten (2OI4), R2P and Jus Post Bellum. In: Stahn, Carsten/Easterday, Jennifer S./Iverson, Jens (Hg.): Jus Post Bellum: Mapping the Normative Foundations. Oxford: Oxford University Press, IO2-I22.

Starlinger, Thomas (2012), The Comprehensive Approach. A Way to Operationalize it in (Post)-Conflict Scenarios, in: Mathis-Moser, Ursula (dir.), Responsibility to Protect, Innsbruck: canadiana oenipontana II, I33I58.

Teubner, Günter (2006), Die anonyme Matrix: Zu Menschenrechtsverletzungen privater, transnationaler Akteure, Der Staat Vol. 45, I6Iff.

Thürer, Daniel (2009), Völkerrecht als Fortschritt und Chance - Grundidee Gerechtigkeit, Vol. 2, Zurich/St Gallen: Edition Dike.

UN Report of the Advisory Group of Experts on the Review of the Peacebuilding Architecture, New York, 30 June 2015, UNGA resolution A/69/968-S/2015/490, http://www.un.org/ga/search/view_doc.asp? symbol=A/69/968 (accessed 04/o2/2018).

UN Report of the High-Level Panel on Peace Operations (Horta Report), New York, I7 June 2015, http://www. un.org/en/ga/search/view_doc.asp?symbol=A/70/95 (accessed 04/02/2018).

UN World Summit (2005), http://www.un.org/womenwatch/ods/A-RES-60-I-E.pdf.

UNDP/Worldbank (2018), Pathways for Peace, Main Messages and Emerging Policy Directions, Washington D.C.: Worldbank.

UNGS Report (2009a), Implementing the Responsibility to Protect, New York, I2 January 2009, UNGA resolution $\mathrm{A} / 63 / 677$.

UNGS Report (2009b), Peacebuilding in the Immediate Aftermath of Conflict, New York, II June 2009, UNSC resolution $\mathrm{S} / 2009 / 304$.

UNOCHA (2017), New Way of Working, New York/Geneva: OCHA Policy Development and Studies Branch, www.unocha.org, www.reliefweb.int.

Verdirame, Guglielmo (2013), What to Make of Jus Post Bellum: A Response to Antonia Chayes, in: European Journal of International Law Vol. 24 No. I, 307-313.

Vienna 3C Appeal, http://www.entwicklung.at/ fileadmin/user_upload/Dokumente/Publikationen/ Downloads_Themen_DivBerichte/Friedensfoerderung und_Konfliktpraevention/Wiener_3C_Appell_o4. pdf (accessed 04/o2/2018).

Werther-Pietsch, Ursula (2017), „A Theory of Change in Times of Crisis". Unter neuem Dach: Impulse der neuen EU Globalstrategie auf die Interaktion von militärischem und zivilem Krisenmanagement, in: Military Interventions, Between Prohibition of Force and the Responsibility to Protect, published by the International Institute for Peace.

Werther-Pietsch, Ursula (2014), Menschliche Sicherheit im Spannungsverhältnis zwischen Souveränität, 
territorialer Integrität und Nicht-Intervention, in: Benedek, Wolfgang/Folz, Hans-Peter/Isak, Hubert/ Kettemann, Matthias C./Kicker, Renate (eds.), Bestand und Wandel des Völkerrechts. Beiträge zum 38. Österreichischen Völkerrechtstag 20I3. Frankfurt am Main: Peter Lang, 27-54.

Werther-Pietsch, Ursula (2015), Staat und/oder Gesellschaft - Statebuilding III: Die Bedeutung von Selbstbestimmung im Staatsaufbau, IE Working Paper No. 6, November 2015, University of Vienna.

Werther-Pietsch, Ursula (forthcoming), Sustained Peace in Normative Terms. An invitation, in: Austrian Review of European and International Law.

Werther-Pietsch, Ursula/Ritzer, Thomas (2013), Peacekeeping und die neue Interventionslogik, in: Frank, Johann/Matyas, Walter (eds.), Strategie und Sicherheit. Vienna: Böhlau, 87-98.

World Bank (200I), World Development Report on Conflict, Security, and Development, Washington D.C., http://siteresources.worldbank.org/INTW DRS/Resources/WDR2OII_Full_Text.pdf (accessed O4/02/2018).

\section{Author}

Ursula Werther-Pietsch is Assistant Professor in International Law at the University of Graz since 2012. She teaches at Universities of Vienna and Graz as well as three Campus Universities as well as the Austrian National Defense Academy and Diplomatic Academy Vienna. Werther-Pietsch is Deputy Director at the Austrian Ministry for Europe, Integration and Foreign Affairs. In 2017 she founded the Master of Science in Global Peace and Security at Danube University Krems. Numerous publications, i.a. Failed States - Staatsaufbau als Konfliktprävention (2012), Berlin-Wien-Graz: Neuer Wissenschaftlicher Verlag, and Global Peace and Security - International Crisis and Conflict Management (2017), Studienbuch MANZ.

Research areas: Human rights, human security, security and fragility nexus, peacebuilding and statebuilding discourses, EU and UN law, international relations, development policy, international crisis and conflict management, focus on international law of transition. 